\title{
Are Suburban TODs Over-Parked?
}

\author{
Robert Cervero, Arlie Adkins, and Cathleen Sullivan \\ University of California, Berkeley
}

\begin{abstract}
A survey of 31 multi-family housing complexes near rail stations in the San Francisco Bay Area and Portland, Oregon, show peak parking demand is 25-30 percent below supplies and, for most projects, falls below national standards. Peak parking demand is generally less for less expansive projects with short walking distances to rail stations that enjoy frequent peak-period services. Case study experiences suggest that welldesigned, short and direct walking paths to rail stops lessen peak parking. A national survey of 80 U.S. cities with rail stations revealed that 75 percent have minimum TOD parking requirements that mandate more parking than suburban design standards and 39 percent grant variances for housing projects near rail stops.
\end{abstract}

\section{Parking and Transit in the U.S.}

Excessive parking could explain why transit-oriented development (TOD) in the United States often has failed to yield hoped-for benefits, such as big ridership gains and less traffic congestion. Critics charge that many large-scale housing projects near urban rail stations are "over-parked"-more parking is provided than is needed (Daisa 2004; Dunphy et al. 2004). This can drive up the cost of housing, consume valuable land near transit, and impose such environmental costs as increased impervious surface area.

Part of the blame for the surfeit of parking in TODs could be the reliance on parking generation figures from the Institute of Transportation Engineers (ITE). Implicitly, ITE standards assume that car ownership levels are no different in rail-served and non-rail-served areas. Outdated parking standards have a way of perpetuating 
themselves. A study of Southern California communities, for example, found the vast majority based their parking requirements on those of surrounding communities or ITE standards, and only 3 percent conducted their own parking studies (Willson 2000).

Research suggests neighborhoods designed according to TOD principles, including below-norm parking, are associated with lower car ownership rates (Dunphy 2004; Cervero et al. 2004; Renne 2009b), appreciably higher transit modal splits for commuting (Cervero 1994; Lund et al. 2006), and fewer vehicle trips per day (Cervero and Arrington 2008). In 2000, the number of AM peak vehicle trip ends per dwelling unit was measured at 0.17 for the Rosslyn-Ballston TOD corridor in Arlington County compared to an ITE average for similar housing of $0.54-$ a threefold differential (Cervero et al. 2004).

The full cost of excessive parking supplies is large (Shoup 2005). From the private consumer standpoint, mandatory parking codes (e.g., two off-street spaces per dwelling unit) unnecessarily drive up the price of housing (Poticha and Wood 2008). Podium, tuck-under parking, or underground parking spaces can add upwards of $\$ 60,000$ to the cost of housing in pricey markets such as the San Francisco Bay Area. Requiring more parking than is needed also deters central-city redevelopment, thus shifting growth to auto-oriented suburbs (Loukaitou-Sideris and Banjeree 2000; Hess and Lombardi 2004). From a larger societal standpoint, excess parking supplies impose such costs as inordinate land consumption (particularly in the case of surface lots); creation of more impervious surfaces that pollute streams and water supplies as well as raise temperatures (through heat-island effects); increased separation of buildings, which deters walking and encourages motorized travel; and the blemishing of natural landscapes.

Why might parking demand fall below parking supply for TOD housing projects? Part of the explanation is "self-selection"-for lifestyle reasons, including the desire to transit commute and reduce household expenditures on cars, people move into neighborhoods well-served by transit (Boarnet and Crane 2001). Using nested logit analysis, a recent San Francisco Bay Area study estimated that 40 percent of the increased odds of rail commuting among TOD residents are due to selfselection (Cervero 2007).

Why, then, do planners continue to use ITE parking generation numbers? One reason is that it is difficult to break away from standard practices in the transportation field, often for political reasons, such as a fear among businesses of insufficient customer parking and among residents that parking will spill into their neighbor- 
hoods (Shoup 2005). In the past, the Urban Land Institute recommended that suburban commercial projects be parked above conventional standards as a "marketing advantage" and cautioned "when in doubt, over-build parking" (Dunphy 2004). Remarked the developer of a recently opened 449-unit apartment building atop a Los Angeles subway station: "We never reduce the amount of parking at our developments. People still want their cars," adding that "Nothing would make us happier than to reduce the expensive underground parking" (Karp 2008).

Continued reliance on ITE numbers to judge the parking needs of new transitoriented housing is cause for concern, given the growing market demand for housing near transit. The Urban Land Institute (2004) has estimated that around one-third of newly-formed households in large metropolitan areas of the U.S. are highly receptive to TOD living. The Center for Transit Oriented Development (CTOD) predicts that the demand for housing near transit in America will more than double by 2030 (Poticha and Wood 2009).

This study empirically investigates the proposition that TOD, and specifically housing near suburban rail stops, is "over-parked" in the U.S. This is done by comparing parking generation rates for 31 housing complexes near rail stops in the San Francisco Bay Area and Portland, Oregon, with on-site parking supplies and with ITE parking generation rates. The ITE rates, representing averages for mostly suburban settings in the U.S., effectively serve as the "control group." Factors that explain parking demand also are investigated, both statistically and through case analyses. The results of a national survey on parking codes of 80 U.S. cities with rail stops also are presented. The paper ends with several policy prescriptions that fall out of the research findings.

\section{Empirical Analysis}

To compare actual parking demand to supply levels and ITE rates, data were compiled for 31 multi-family rental housing projects in two rail-served areas: Metro Portland, Oregon (15 projects) and the East Bay of the San Francisco-Oakland Bay Area (16 projects). These two regions were chosen, in part, to compare results to a recent study of TOD vehicle trip generation rates conducted in both areas, published in this journal (Cervero and Arrington 2008). All of the surveyed housing projects were within two-thirds of a mile of the nearest rail stop (the mean straight-line distance was 1530 feet, or a little over a quarter mile). We refer to 
these projects as "transit oriented" purely in terms of their walkable proximity to a rail stop.

Table 1 summarizes key attributes of the projects, organized by the four BART (Bay Area Rapid Transit) heavy-rail stations in the East Bay and the nine MAX lightrail stations in Metro Portland that were closest to the projects. The ITE mean estimated parking generation rate is 1.2 vehicles per unit at peak periods. Table 1 shows that parking supplies clearly exceed this figure in most cases: at only one of the 13 rail stations in Portland (E. 162 Ave.) was the average parking supply of all nearby multi-family housing projects below the ITE rate (and just barely). Among the 31 individual projects, only two (Sequoia Square near the E. 162 Ave. station and Diablo Oaks near the Pleasant Hill BART station) had fewer than 1.2 spaces per dwelling unit. The number of parking spaces per dwelling unit for all 31 projects (i.e., the weighted average statistic) was 1.57 , or about 31 percent above the ITE standard. Housing projects in the East Bay had particularly inflated parking supplies relative to ITE's standards.

Given the suburban setting and character of most surveyed projects, many featured garden apartment designs. Of the 31 projects, 17 were 3 stories in height, 11 were 2 stories, and 4 were 4 stories. Table 1 reveals the expansiveness of many projects, with the surface area (devoted to parking, driveways, open spaces, swimming pools, etc.) typically being more than twice as large as the footprint of the buildings. Among the 31 projects, the mean building coverage rate was 31 percent, ranging from 18 percent to 54 percent. Projects in Metro Portland tended to be closer to stations than in the East Bay. East Bay projects, however, were generally in denser neighborhoods with relatively higher incomes.

\section{Data Collection}

Housing projects that were suburban in character and within walking distance of rail stops in both regions were chosen for the study. Efforts also were made to collect data from some of the same projects used to study TOD trip generation (Cervero and Arrington 2008). Further winnowing down the sample frame was the agreement of property owners and building managers to allow the research team to collect data on site. This was not always easy because of (1) when data were collected-the wee hours of the morning when most tenants are at home asleep, thus constituting "the peak"; and (2) how data were collected-driving through each project and visually counting parked cars. In the end, 31 property owners and managers agreed to let the research team on their sites to compile data. 


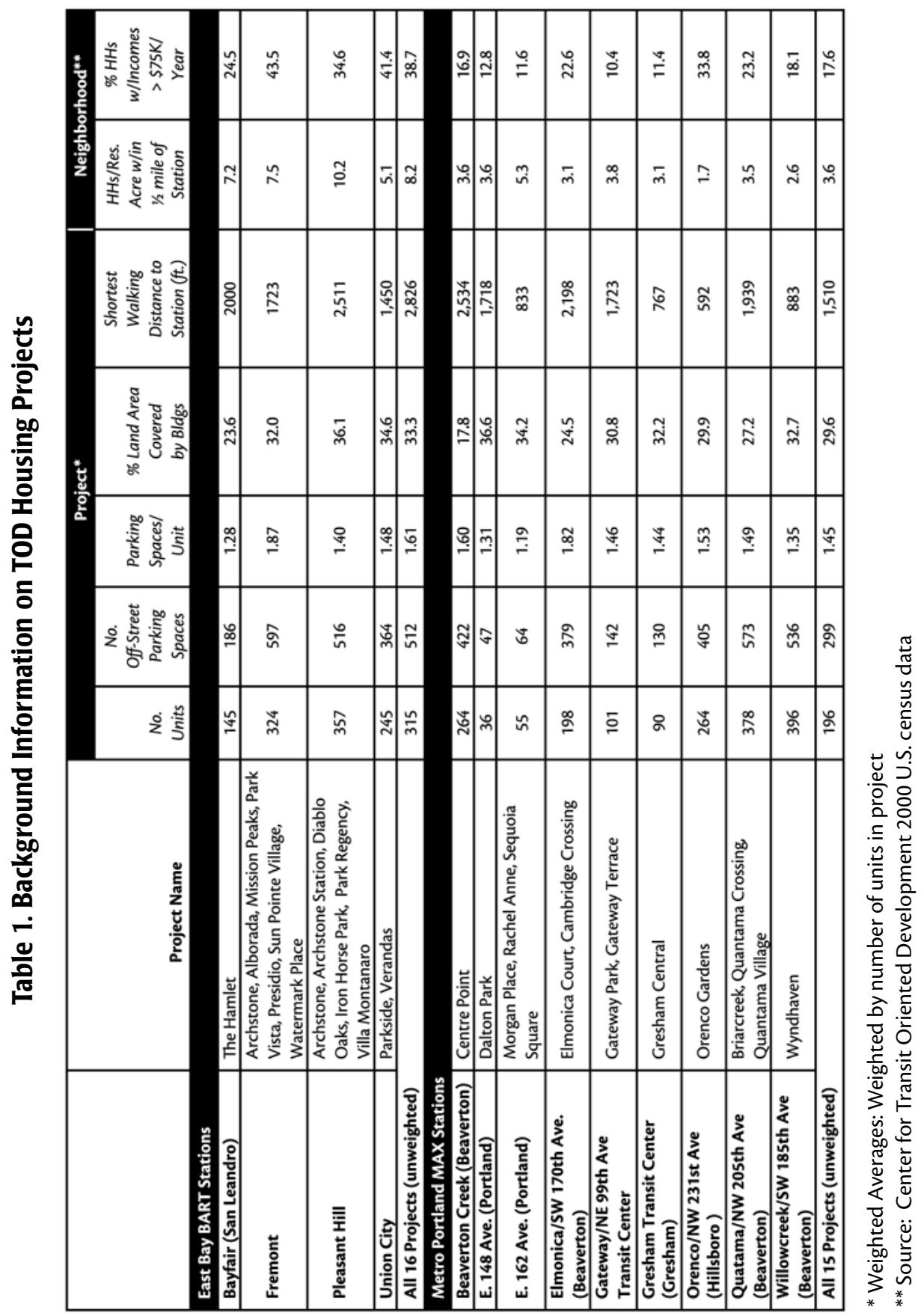


Empirical data were collected during the late spring and early fall of 2008, corresponding to the non-rainy period of both regions when school was still in session, both considered to be peak conditions for parking. All parking counts were made on a mid-week day when the odds of someone being away for an extended weekend were the least. Data on the number of cars parked in on-site parking stalls (including smaller stalls for motorcycles) were collected during both the peak period (defined as 12 midnight to 5 a.m.) and the off-peak (10 a.m. to 2 p.m.).

\section{Comparison of Parking Generation Rates}

Given that most surveyed housing projects had parking supplies that exceeded ITE standards, was the seemingly over-supply of parking backed up by demand numbers as well? That is, is there empirical evidence that TODs are over-parked?

Parking demand levels recorded for the surveyed projects were compared to the number of parking stalls as well as rates from the 2003 ITE manual for "Low/MidRise Apartments" (Land Use Category 221) in suburban locations. As noted, ITE's average rate of peak parking on weekdays is 1.2 vehicles per unit. This is a weighted average drawn from 19 data observations. (The ITE manual defines weighted average as the sum of parked vehicles for all projects divided by the number of dwelling units.)

The weighted-average peak-parking demand for all 31 projects was 1.15 . This is 27 percent below the weighted-average peak parking supply shown earlier in Table 1 (i.e., $1-1.15 / 1.57 \approx 0.27$, or $27 \%$ ). It is just 4 percent below the ITE rate, however (i.e., $1-1.15 / 1.20 \approx 0.04$, or $4 \%$ ). For Metro Portland, the weighted average demand was 1.07 parked vehicles per dwelling unit, and for the East Bay, it equaled the ITE target-1.2.

Figure 1 breaks down the findings for the 31 individual projects. In Metro Portland, peak parking occupancies were less than supplies in all instances and less than the ITE rate for 12 of the 15 surveyed projects. In the case of the 57-unit Gateway Terrace apartment complex near the MAX's Gateway Station, parking demand was less than half the ITE average rate and two-thirds below supply levels (i.e., only one third of stalls were occupied). Factors such as relative high vacancy rates could explain lower demand for some of these projects; however, in general, vacancy rates for surveyed rental projects were similar to regional averages and implicitly, we assume, to projects in the ITE database. We acknowledge, however, that empty rental units translate into empty parking stalls and, in some instances, relatively low parking demand could be a result of relatively high vacancy rates. 

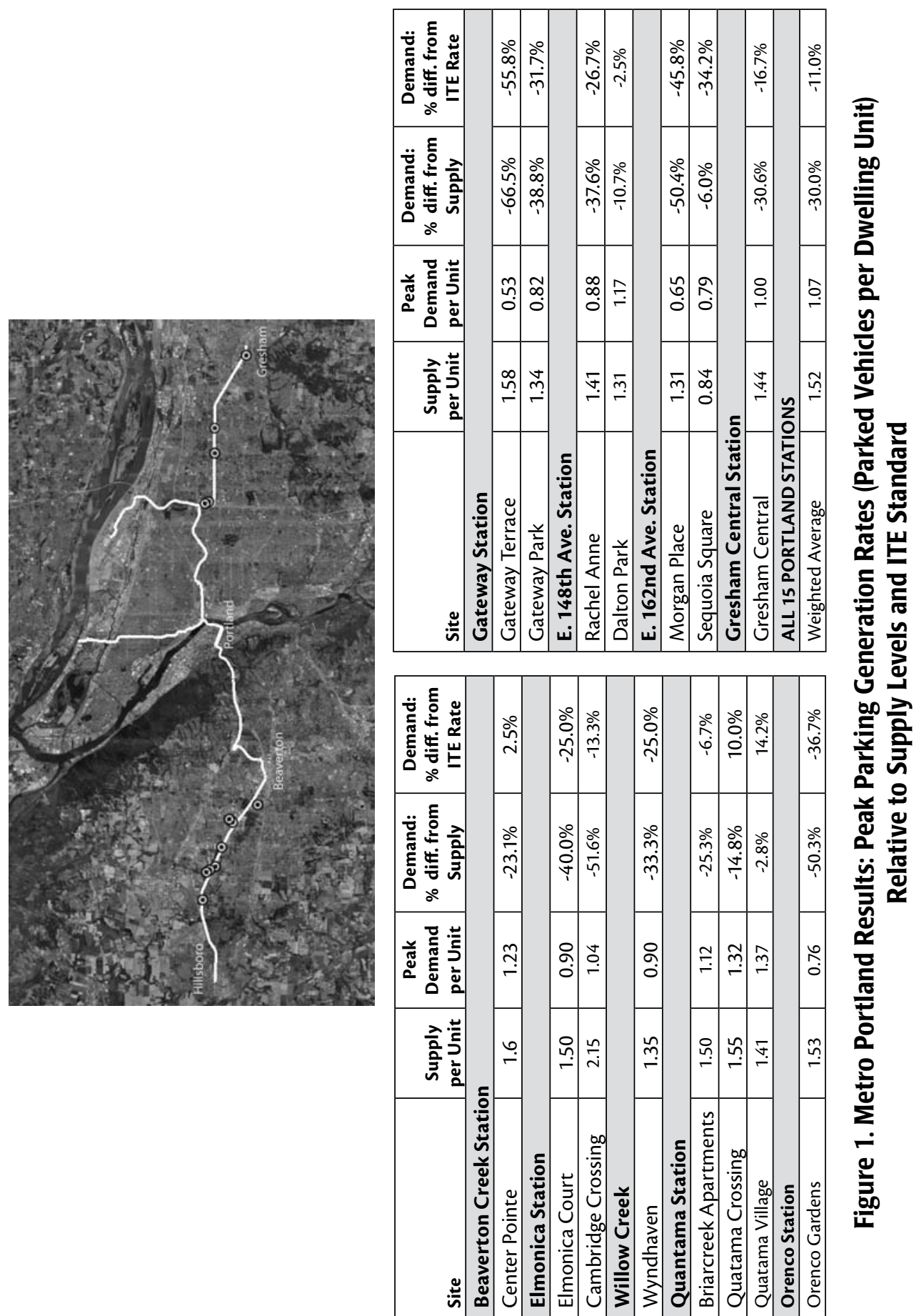


\begin{tabular}{|c|c|c|c|c|c|c|c|c|c|c|c|c|c|c|c|c|c|c|c|c|c|}
\hline 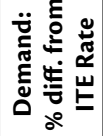 & & ळे & ले & $\begin{array}{l}\stackrel{े}{\tilde{m}} \\
\stackrel{\tau}{\text { Tे }}\end{array}$ & $\mid \begin{array}{l}\stackrel{0}{2} \\
\dot{\Gamma} \\
\end{array}$ & $\mid \begin{array}{c}\text { خे̀ } \\
\text { ì }\end{array}$ & $\stackrel{\stackrel{\leftrightarrow}{\circ}}{\stackrel{\circ}{\sim}}$ & & 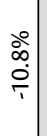 & & ํํㄹ & $\begin{array}{l}\diamond 0 \\
\infty \\
i \\
i\end{array}$ & & $\stackrel{\circ}{\stackrel{\circ}{0}}$ & 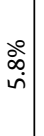 & $\begin{array}{l}\stackrel{\circ}{\hat{i}} \\
\stackrel{\sim}{i}\end{array}$ & $\begin{array}{l}\stackrel{0}{\infty} \\
\stackrel{\text { i }}{ }\end{array}$ & 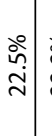 & 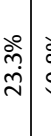 & & \\
\hline 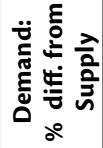 & & ڤั? & $\begin{array}{l}\stackrel{\circ}{N} \\
\stackrel{m}{1}\end{array}$ & 官 & 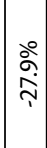 & 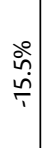 & 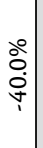 & & 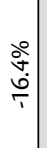 & & $\begin{array}{l}\text { ठें } \\
\text { ஸें }\end{array}$ & 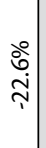 & & 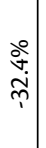 & $\begin{array}{l}\text { ○े } \\
\dot{m}\end{array}$ & 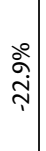 & $\begin{array}{l}\stackrel{\circ}{\circ} \\
\text { ঠे }\end{array}$ & 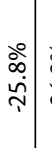 & & $\frac{\stackrel{\circ}{r}}{\dot{r}}$ & \\
\hline 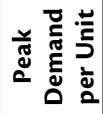 & & 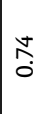 & $\begin{array}{l}\stackrel{8}{0} \\
0\end{array}$ & $\tilde{\sigma}$ & \begin{tabular}{l}
0 \\
\hdashline \\
\hdashline
\end{tabular} & 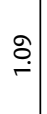 & $\stackrel{\overbrace{}}{r}$ & & $\stackrel{\text { ô }}{r}$ & & $\underset{\ulcorner}{\check{C}}$ & $\stackrel{m}{\rightleftarrows}$ & & 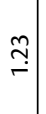 & 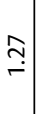 & $\stackrel{\dddot{m}}{r}$ & $\stackrel{\stackrel{\sim}{r}}{r}$ & $\stackrel{f}{\leftarrow}$ & 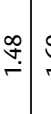 & 움 & 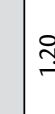 \\
\hline 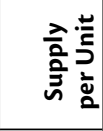 & 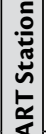 & $\stackrel{\stackrel{n}{\circ}}{r}$ & $\stackrel{\mathcal{N}}{\leftarrow}$ & 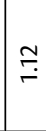 & $\underset{\sim}{\stackrel{f}{-}}$ & 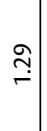 & $\begin{array}{l}n \\
\stackrel{n}{i} \\
\text {. }\end{array}$ & $\stackrel{5}{\circ}$ & $\stackrel{\sim}{\sim}$ & & $\begin{array}{l}\stackrel{0}{\stackrel{n}{r}} \\
\end{array}$ & 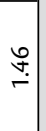 & & $\stackrel{\sim}{\infty}$ & $\begin{array}{l}\stackrel{⿱ 亠 凶}{+} \\
\leftarrow\end{array}$ & 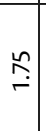 & $\stackrel{\infty}{\stackrel{\leftrightarrow}{\leftarrow}}$ & 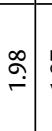 & 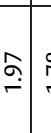 & $\stackrel{\infty}{\stackrel{\infty}{+}}$ & 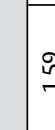 \\
\hline 苾 & 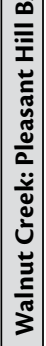 & $\begin{array}{l} \\
\frac{\tilde{v}}{\tilde{0}} \\
\frac{0}{0} \\
\frac{0}{0} \\
\frac{\pi}{0}\end{array}$ & 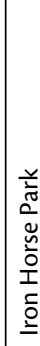 & 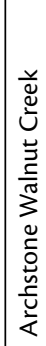 & 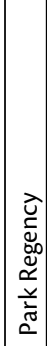 & 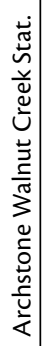 & 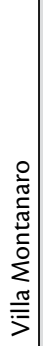 & 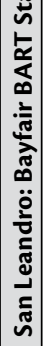 & 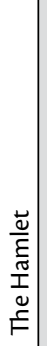 & 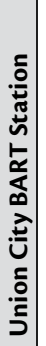 & 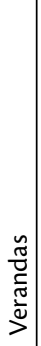 & $\begin{array}{l}\frac{0}{\frac{\pi}{2}} \\
\frac{2}{\bar{c}} \\
\frac{c}{c}\end{array}$ & 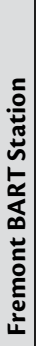 & 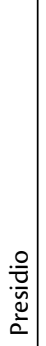 & 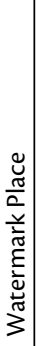 & 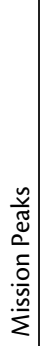 & 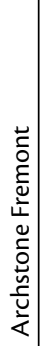 & 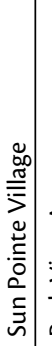 & 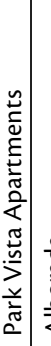 & 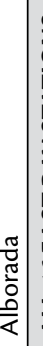 & 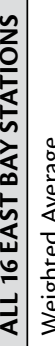 \\
\hline
\end{tabular}

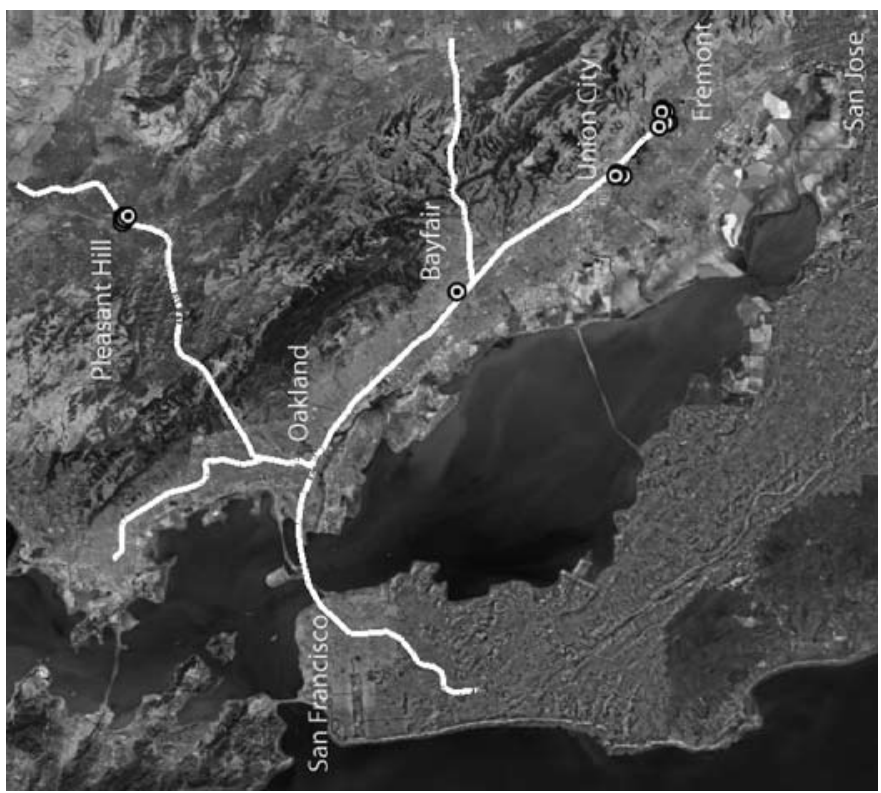

里

y

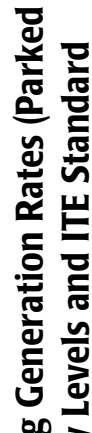

을 글

츨 흘

동 웅

ญ

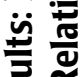

पे

$\propto$

空

芯

훙 
In the East Bay, owning and parking a car seemed to be a bit more of a necessity for TOD residents. None of the surveyed East Bay lots was saturated, with, on average, around 25 percent of stalls empty; however, this occupancy rate was higher than in Metro Portland. The weighted average parking rate of 1.2 for East Bay sites matched ITE's standard, though with a fair amount of variation. At three of the four East Bay stations, nearby parking demand was considerably less than the ITE rate. Below-rate parking levels characterized most projects near the Pleasant Hill BART station, one of the East Bay's first "transit villages" (Bernick and Cervero 1997). The Fremont BART station is an outlier, inflating the East Bay average. For all projects near Freemont BART, parking levels exceeded the ITE rate, by as much as 41 percent.

In general, overestimation of parking demand suggests people are shedding cars, taking advantage of the accessibility benefits of living near high-quality transit. Fewer cars per household should translate to fewer parked cars. Little is known about car ownership levels for the surveyed projects however some insights can be gained from modal split statistics. In the East Bay, a 2003 survey of residents living in the Verandas Apartments near Union City BART and Park Regency near Pleasant BART found that 54 percent and 37 percent, respectively, commuted to work by transit (versus a 2000 census figure of $10.6 \%$ of commuters in the nine-county San Francisco Bay Area) (Lund et al. 2004). These high transit mode splits were matched by our findings of relatively low parking demand: 8 percent and 12 percent below the ITE rate for Verandas and Park Regency, respectively. While none of the Metro Portland projects in our sample have been surveyed for modal splits, one study estimated the share of commute trips by transit among those living within $1 / 2$ mile of the Elmonica and Orenco MAX Stations at 30 percent and 24 percent, respectively (versus a 2000 census transit commute share of 6.4\%) (Dill 2006). Our surveys found peak-parking demands considerably below ITE rates for both stations (see Figure 1).

While car-shedding no doubt occurs among those living near transit, it might not be as extensive as assumed, particularly among those living in car-dependent suburbs. This is suggested by comparing the differentials between parking generation rates and vehicle-trip generation rates relative to their respective ITE manuals. A recent study of five TOD housing projects in the East Bay and five in Metro Portland found clear evidence of "trip de-generation": the weighted average of vehicle trip rates were 40 percent and 27 percent below that estimated by ITE trip generation rates (Cervero and Arrington 2008). As shown in Figure 1, the weighted differential for parking generation matched the ITE rate for East Bay projects and was 11 percent below for Metro Portland projects. Owning and parking a car was particularly a necessity for Fremont's TOD residents. 
What's going on? It is likely that in most suburban TODs, which characterizes the 31 projects in our survey, residents still need access to a car. They just do not use them as much to get to work. But like most suburbanites, they still need a car to get to most non-work destinations, the vast majority of which are away from rail stops. While transit-oriented housing might mean that more trip origins are near rail stops, as long as most destinations are not, many TOD residents still will own cars and use them for shopping, going out to eat, and the like. One policy response to this finding, discussed in the conclusion, is to create car-sharing programs in rail-served neighborhoods. Car-sharing would enable residents not only to railcommute but also to shed one or more cars.

\section{Why Do Rates Vary?}

To probe factors that might explain why peak parking demand varies among transit-oriented housing projects, this section presents several best-fitting multiple regression equations. The influences of both on-site and off-site factors on parking demand are investigated. Among on-site factors considered as possible predictors were parking supplies, project size (e.g., land acreage), project density (e.g., land coverage percentages, dwelling units per acre), project design (e.g., whether a gated project, whether surface or structured parking), distance to the region's CBD, and average rents (a proxy for tenant income levels). A longer list of off-site candidate variables was also considered for model entry, including walking distance, a circuitry index, transit service levels (e.g., headways), road designs (e.g., road widths and presence of nearby freeway interchange), and a number of variables denoting neighborhood attributes within $1 / 2$ mile of stations, including housing density, income levels, and the presence of retail shops. This analysis thus draws from a substantial literature that holds that various built-environment factors, such as urban densities and walking quality, have a significant bearing on travel behavior (Ewing and Cervero 2001; Handy 2005).

Table 2 presents the best-fitting multiple regression equation for predicting peak parking demand that yielded results consistent with theory and expectations. The two most significant on-site factors-parking supply and project land area-were strongly associated with increased parking demand. These two factors probably are not independent since more spacious land area allows for more parking supply and, in general, a more car-oriented built environment (e.g., wider internal roads). Holding other factors constant, the model estimates that reducing parking by 0.5 spaces per unit will lower peak demand by 0.11 parked cars per unit. 


\section{Table 2. Best-Fitting Multiple Regression Equation for Predicting Peak Parking Rates}

\begin{tabular}{|c|c|c|c|c|}
\hline & \multicolumn{4}{|c|}{$\begin{array}{l}\text { Dependent Variable: } \\
\text { Peak Parking per Dwelling Unit }\end{array}$} \\
\hline & Coeff. & Std. Err. & t Statistic & Prob. \\
\hline Parking Supply: Parking spaces per dwelling unit & 0.225 & 0.122 & 1.84 & .077 \\
\hline Land Area: Project's land acreage & 0.001 & 0.006 & 2.254 & .033 \\
\hline $\begin{array}{l}\text { Walking Distance: Shortest distance along sidewalk } \\
\text { network from project center to station, in } 1000 \mathrm{ft}\end{array}$ & 0.689 & 0.307 & 2.223 & .035 \\
\hline $\begin{array}{l}\text { Peak Rail Headways: Minutes between trains in AM } \\
\text { peak at nearest station }\end{array}$ & 0.059 & 0.019 & 3.111 & .005 \\
\hline Metro Portland Project: $1=$ yes; $0=$ no & -0.182 & 0.078 & -2.341 & .028 \\
\hline Constant & 0.122 & 0.199 & 0.615 & .544 \\
\hline $\begin{array}{l}\text { Summary Statistics: } \\
\qquad \text { F statistics (prob.) }=10.657(.000) \\
\text { R Square }=.681 \\
\text { Number of Cases }=31\end{array}$ & & & & \\
\hline
\end{tabular}

Among off-site factors, the only two candidates that yielded statistically significant results were walking distance and peak headways of nearby rail services. The model suggests that for every 1,000 feet of walking distance that a project lies away from a station, peaking parking can be expected to increase by 0.7 cars per dwelling unit, all else being equal. Longer headways, denoting less frequent train services, also seem to be an inducement to car ownership and high peak parking demand. A fifth variable in the equation, "Metro Portland Project," served as a fixed-effect control, denoting less peak parking demand in Metro Portland vis-à-vis East Bay projects. Fixed-effect factors aim to capture the uniqueness of observations from the same city; thus, the significance of this variable could be capturing Portland's legacy as a pro-transit, smart-growth setting.

While Table 2 reveals a model with fairly good statistical fits-explaining twothirds of the variation in peaking parking demand-some variables that we felt might be significant were not. Notably, once controlling for walking distance, the circuity of the walk was not significant. This is consistent with findings from other studies showing that quality of walking environment and micro-design features (e.g., presence of street trees) have relatively little influence on travel behavior among those living within five minutes of a station (Cervero 2001; Lund et al. 
2004). Other non-significant predictors included project density, rent levels, and socio-demographic characteristics of the surrounding neighborhood.

Figure 2 presents a sensitivity analysis of the two variables over which TOD housing developers have some influence: parking supplies and walking distance to a station. Based on the best-fitting multiple regression equation and using mean values for other predictors (i.e., 8 acres of land surface and 8-minute AM peak headways), the figure plots predicted peak parking demand over a range of parking supply and walking distance data. This plot applies to Metro Portland cases (i.e., the variable "Metro Portland Project" was set at 1); however, the same patterns hold for East Bay projects as well (notably, the Y-intercepts of the sloping lines simply slide up by a value of 0.182 ). For example, the model predicts that at 1.25 parking spaces per unit (roughly ITE's recommended rate) at 500 feet walking distance from a station, peak parking demand is slightly above 1 space per dwelling unit. At a generous supply of 1.75 spaces per unit and a quadrupling of distance to 25,000 feet, it shoots up to 2.5 parked cars per dwelling unit. Clearly, supply and distance matter.

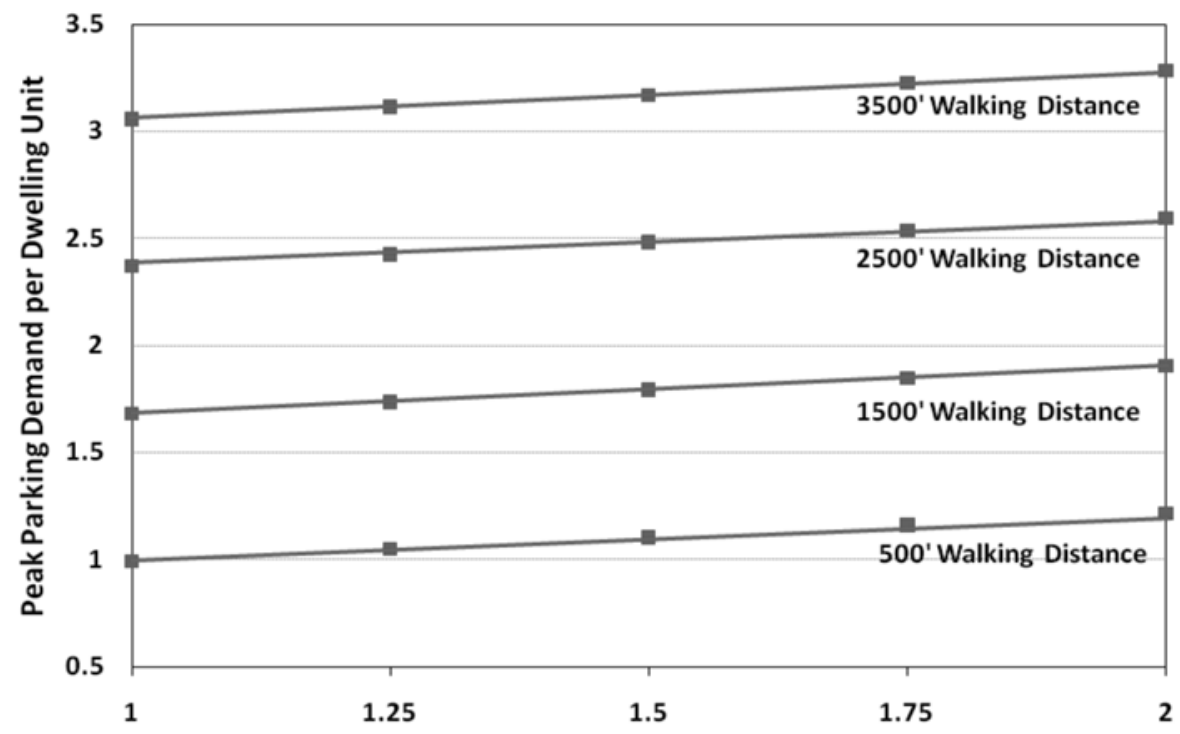

Number of Parking Spaces per Dwelling Unit

Figure 2. Sensitivity Analysis: Influences of Parking Supplies and Walking Distances on Predicted Peaking Parking Demand 
One additional multiple regression equation was estimated to shed light on transit usage among TOD tenants. The dependent variable is off-peak parking demand divided by peak parking demand. A high value denotes that significant shares of tenants are leaving their cars at home during daylight hours and thus presumably commuting by transit-i.e., there are almost as many parked cars in the midday as in the wee hours of the morning. Very low values suggest the obverse: most tenants are driving to work or other destinations.

Numerous available variables were used as candidate predictors; however, as shown by the best-fitting equation in Table 3, only two were reasonably significant: land area and walking distance. The coefficients on both variables are negative, indicating that large, spacious projects far removed from stations were associated with most tenants driving to work-i.e., parking lots tended to empty out during the day.

\section{Table 3. Best-Fitting Multiple Regression Equation for Predicting the Rate of Off-Peak to Peak Parking Demand}

\begin{tabular}{|l|c|c|c|c|}
\hline \multirow{2}{*}{} & \multicolumn{4}{|c|}{$\begin{array}{c}\text { Dependent Variable: } \\
\text { Off-Peak Parking/Peak Parking }\end{array}$} \\
\cline { 2 - 5 } & Coeff. & Std. Err. & $t$ Statistic & Prob. \\
\hline Land Area: Project's land acreage & -0.009 & 0.003 & -2.493 & .019 \\
\hline $\begin{array}{l}\text { Walking Distance: Shortest distance along sidewalk } \\
\text { network from project center to station, in 1000 ft }\end{array}$ & -0.244 & 0.000 & -1.651 & .110 \\
\hline Constant & 0.688 & 0.041 & 16.766 & .000 \\
\hline $\begin{array}{l}\text { Summary Statistics: } \\
\text { F statistics (prob.) }=6.073(.006) \\
\text { R Square }=.303 \\
\text { Number of Cases }=31\end{array}$ & & & & \\
\hline
\end{tabular}

\section{Case Studies}

The previous analysis showed that walking distance and parking supplies were the two most significant predictors of parking generation rates. Several case examples around the Fremont BART Station amplify this point. Projects near the Fremont BART station stand out for their high peak parking rates, ranging from 1.23 to 1.69. Alborada Apartments is notable for having the highest peak parking demand of the entire study. Another site, Archstone Fremont Center, distinguishes itself not because its peak generation is unique (at 1.45, its rate is average for Fremont) 
but because its off-peak generation is so high. The off-peak parking generation at Archstone was 1.14, the highest of all surveyed projects. That is, almost 80 percent of the cars present in the middle of the night were still there in the middle of the day. Archstone's high ratio (0.78) of off-peak to peak demand indicates that most residents own cars but are not driving for their daily commute. What neighborhood and design features might explain the seemingly high level of car parking and use at the surveyed Fremont projects? Focusing on these two "outlier" cases might shed light on this question.

\section{Fremont Station Area}

The city of Fremont was designed for the car (Renne 2009a). Despite the presence of pedestrian and bicycle infrastructure, such as audible pedestrian countdown signals, bike lanes, and wide, shaded sidewalks, it is not an inviting place to walk or bike due to its scale and the vast distances that separate activities. The streets immediately adjacent to the Fremont BART station are quite wide, ranging from 80 to 100 feet, and the blocks are 800-2000 feet long. Over half of the surveyed projects in Fremont are more than 13 acres in size. A block away from the Fremont station lies large office and institutional buildings that turn large blank walls to the sidewalk. Retail stores and eateries are few and far between.

\section{Fremont BART's Archstone and Alborada Projects}

A comparison of Archstone and Alborada reveals several salient differences that could explain variations in parking demand. One difference pertains to on-site uses. Ground-floor retail uses at Archstone (a coffee shop, grocery store, and restaurants) enable residents to meet basic daily needs on foot en route to or from the BART station. In contrast, Alborada has no retail on-site or along the walkway to BART. This could partly explain why larger shares of Archstone residents leave their cars at home during the workday-i.e., its relatively high off-peak to peak parking ratio.

Another difference pertains to site design. Both Archstone and Alborada are relatively large complexes, with 323 and 442 units, respectively, but the projects have strikingly different physical forms (Photo 1). Alborada is a garden-style project with individual buildings interlaced by surface parking. It is an insular, gated development, set back from the street and detached from its surroundings. Over 16 acres in size, it averages 27 units per acre. Two-thirds of Alborada's land area is devoted to surface parking and roadways. In contrast, at 54 units and covering only 6 acres, Archstone is more compact, conveying the feeling of an urban place. Cars have 
less of a physical presence: podium parking is tucked under four-story residential complexes, with less than half the site devoted to parking and roadways.

\section{Photo 1. Contrasting Road Designs}

Alborada Apartments (above) and Archstone Fremont Center (below)
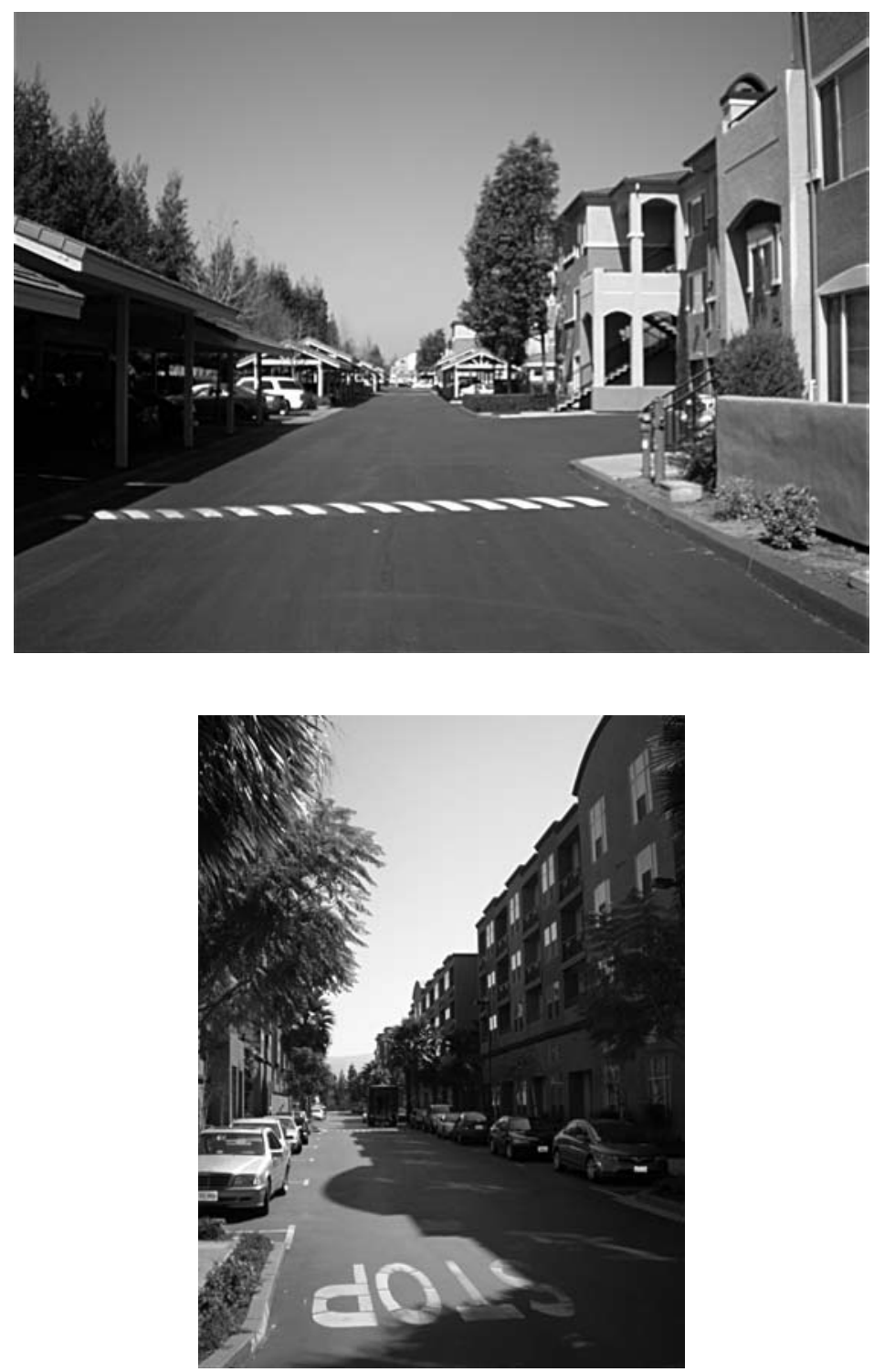
It is not form alone but also how Alborado's design affects connectivity to BART that likely influences travel choices. Despite Alborada lying within a half mile of BART, the shortest walking route to the station is over a mile (Photo 2). This circuity results from two factors: (1) the entire perimeter of Alborada's16-acre expanse is fenced and the sole gate is at the opposite end from the station; and 2) the sheer size of the development, together with limited access points, inflates walking times to almost anywhere. It takes around six minutes to walk from one end of the Alborada complex to the other. Even Alborada residents who take transit may be tempted to drive to the station when faced with a choice of a two-minute drive or a circuitous 20-minute walk along a route lacking anything of pedestrian interest. The fact that reaching the local BART station is far more convenient by car than foot likely contributes to Alborada's high peak parking rate.

\section{Photo 2. Trip Circuitry}

Comparison of shortest walking path to straight-line distance from center of Alborada Apartments project to the Fremont BART station entrance.

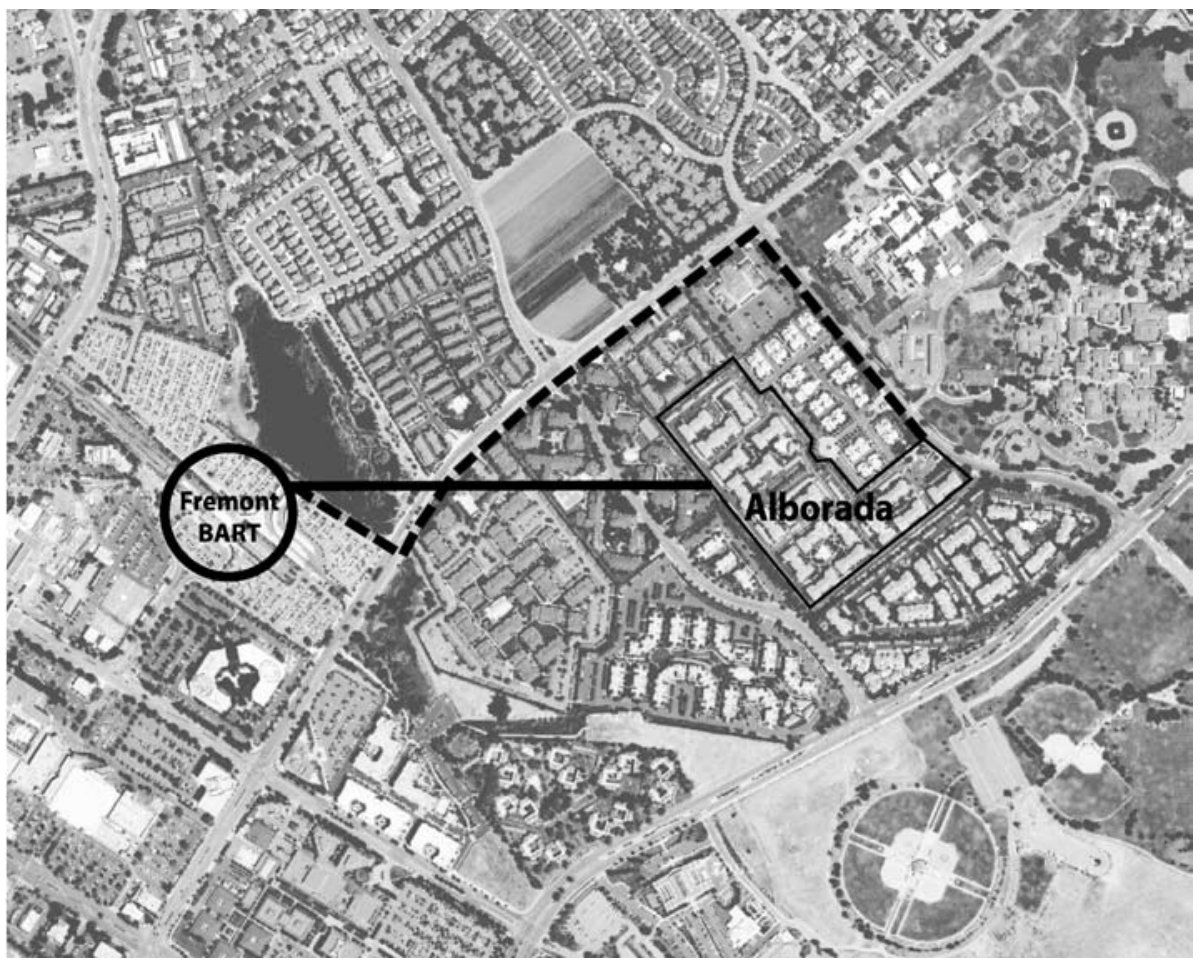


In contrast, Archstone Fremont's considerably higher off-peak/peak parking ratio is no doubt partly due to easier foot access. Most Archstone tenants are within 10 minutes of the BART fare gate. This is due partially to the fact that Archstone is closer to BART than Alborada, which, as shown earlier in Table 3, is a significant predictor of this ratio. Additionally, Archstone's proximity is enhanced by the absence of clear borders and fences. The project's smaller scale and grid layout also create a more pedestrian-friendly setting.

In sum, the Archstone and Alborada cases suggest that the presence or absence of mixed uses, direct pathways, and connectedness to surroundings could very well affect how TOD residents use and park their cars. The Quatama MAX station in Beaverton, Oregon, can serve as a model for cities such as Fremont on designing for transit connectivity. There, a walking path provides direct and nicely-landscaped access to the MAX station (Photo 3 ). The city required the project developer to build the path as a condition of approval. Retrofitting current development with such pathways, while challenging, could improve current pedestrian connectivity, and requiring such pathways in new developments could ensure better connectivity in the future.

\section{Photo 3. Pathway from the Quatama Station toward nearby residences}

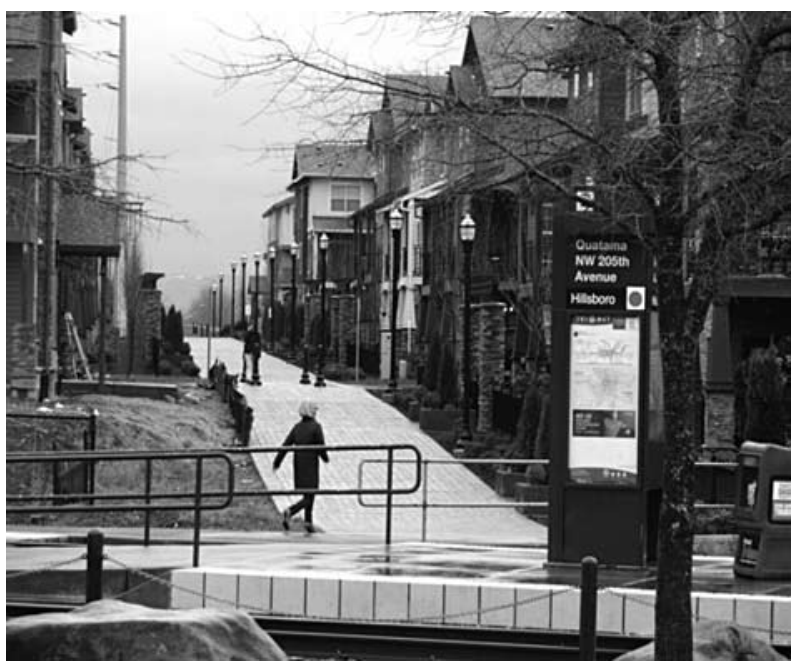




\section{TOD Parking Ordinances}

While our research has found that peak parking levels of housing near suburban rail stops are not significantly below national averages (based on ITE data), we also found that factors such as constrained parking supplies and short walking distances to stations can lower demand. In light of these findings, have cities been responsive through their parking zoning ordinances, making adjustments for projects near rail transit?

\section{National Survey}

To probe this question, we conducted a national survey. The sample frame was all U.S. cities with rail transit stations, identified using coordinates from the Center for Transit-Oriented Development station database. From this list of cities, contact information was gathered and an online survey was sent to senior planning staff.

Of the 363 cities surveyed, 22 percent (or 80 in total) returned a completed questionnaire, which is in line with typical response rates for online surveys (Fink 2003). A higher response rate of 40 percent from cities with over 100,000 residents and a 10 percent response rate from cities under 10,000 skewed the sample to an average population of 167,000 versus 144,000 for all cities with rail stops. Ten or more responses were received from cities in metropolitan Los Angeles, San FranciscoOakland, Chicago, and the Washington-Boston corridor.

\section{Survey Findings}

Of the cities surveyed, nearly all (96\%) have some form of minimum off-street parking requirement for multi-family housing. Most cities with minimum parking requirements (89\%) also allow for variances or exceptions to these minimums. Proximity to rail transit is grounds for a variance in 39 percent of cities that allow variances, which is just over one third of all cities with minimum off-street parking requirements for multi-family housing. Parking space reductions for proximity to rail transit range from fewer than 10 percent to as high as 60 percent, with a mean reduction of 22.8 percent (standard deviation $=13.7 \%$ ).

Differences by housing type and across locations in a city complicate the ability to quantify a city's average or typical parking requirement. In the interest of obtaining some sort of comparison, we calculated per-unit parking requirements in each city for a hypothetical transit-oriented multi-family housing project located $1 / 4$ mile from a rail station using zoning requirement and variance information that was provided. These calculated minimum off-street parking requirements are, of 
course, a simplification and likely miss some nuances of applied zoning codes, but they provide a useful tool for comparing requirements across jurisdictions.

The calculated off-street minimum parking requirements for transit-oriented multi-family housing in our sample ranged from 0 to 3 parking spaces per unit for both one and two bedrooms units. The mean across all cities surveyed was 1.37 stalls per one-bedroom unit and 1.61 per two-bedroom unit, both above the ITE per-unit rate of 1.2. If we assume an even mix of one- and two-bedroom units, our average calculated parking requirement for a hypothetical transit-oriented housing project is 1.48 per unit, well above the ITE average of 1.2 per unit and even above ITE's 85 th percentile of 1.46 per unit. Put another way, 75 percent of cities surveyed have minimum TOD parking requirements that exceed ITE parking generation rates. Based on both ITE rates and the empirical findings presented earlier, these numbers show that even when cities adjust parking requirements to take transit-proximity into account, far too much parking is required.

Respondents also were asked questions about their views on current parking policies and the willingness of elected officials and developers to support changes to parking requirements. When asked about their city's current minimum off-street parking requirements near rail stops, 59 percent of respondents answered they "are about right"; however, 37 percent replied "too much was being required." When asked about the likely stance of local elected officials to lowering minimum off-street parking requirements for multi-family housing near rail transit, 59 percent of those who responded felt officials would be supportive versus 32 percent who thought they would be opposed. Moreover, among those who recorded a response, 85 percent felt elected officials would oppose efforts to eliminate minimum parking requirements even if a project is near a rail stop. However, 55 percent also believed elected officials would support efforts to set a cap on parking for housing near rail transit.

In general, survey respondents felt housing developers were inclined to provide less parking than necessary. Among those answering the question, 60 percent felt that developers of multi-family housing would build too little parking if given the chance. Just 10 percent felt developers would provide too much parking. The prevalence of high minimum parking requirements likely reflects the public sector's fear that, if left to their own accord, private developers will under-supply parking. Planners fear the resulting spillover will affect surrounding neighborhoods, which was cited by respondents as the number one obstacle to enacting zoning reforms. 


\section{Conclusions}

This study posed the question: "Are TODs over-parked?" From a design standard perspective, our response is "probably so." For the 31 surveyed multi-family projects combined, there were 1.57 spaces per dwelling unit, nearly one third higher than ITE's suburban standard of 1.2 spaces per unit. From a supply-demand standpoint, transit-oriented housing also seems over-parked: the weighted-average supply of 1.57 spaces per unit was 37 percent higher than the weighted-average peak demand of 1.15 parked cars per unit. From our national survey responses, there is evidence of over-parking: the estimated average minimum parking requirement for multi-family housing near rail transit was 1.48 spaces per unit, also well above the ITE standard. From a pure demand standpoint, however, it appears that peak parking demand for transit-oriented housing aligns fairly closely with the ITE standard. Experiences in the East Bay and Metro Portland suggest that TODs are only slightly over-parked, if at all. In sum, we believe parking supplies are over-inflated, not due to bloated ITE design standards but other factors, such as developers' fears of insufficient parking to attract prospective tenants or local officials' fears of spillover on-street parking problems in surrounding neighborhoods. It is because of such concerns that municipal parking standards for TOD housing appear on the high side, which probably further induces car ownership and usage-i.e., the classical vicious cycle of supply and demand feeding off each other.

We acknowledge that a simple comparative analysis such as ours has limitations and is certainly not the final word on this subject. For this reason, we have refrained from using words such as "caused" or "proved" in describing relationships. The best we can say is that many suburban TODs appear to have more parking than is needed. In truth, "thumbs-up/thumbs-down" decisions on whether to approve proposed TOD projects rely heavily on the kinds of simple comparisons to ITE rates presented in this paper. They certainly are not based on multinomial logit estimates of transit ridership impacts. While we, no doubt, need more sophisticated studies that probe the influences of parking supplies and policies on travel behavior and car ownership, there is also a need for straightforward comparisons of actual and estimated rates to inform TOD design and approval decisions.

While we conclude that transit-oriented housing seems to be mostly over-parked, the research also points to factors that can moderate demand. As expected, supply matters. From our regression estimates, reducing parking by 0.5 spaces per unit is associated with 0.11 fewer cars parked per unit at the peak. Also, parking demand generally fell as the walking distance to a station shortened. Smaller scale projects 
with less land coverage also average lower parking rates. These findings favor clustered development with good internal pathways that provide fairly short, direct connections to rail stops. Such designs can shrink parking demand and its footprint, unleashing a "virtuous cycle" - i.e., less land is given over to surface parking which, in turn, allows more compact site designs. Last, the other policy lever to lower parking demand is transit service levels. Our model showed that reducing headways between trains reduces parking loads, ostensibly because one is less in need of a car in areas with superb transit services.

Other policy responses also are supported by our findings. One response should be the introduction of more flexibility in parking policies for housing near rail stops. Flexibility can be in the form of enabling projects to provide below-code parking levels when justified-e.g., compact projects with short, direct walking connections to transit and perhaps on-site retail establishments. In their chapter "Ten Principles for Developing around Transit," Dunphy et al. (2004, p. 174) note that "flexible parking standards provide some latitude in providing the optimal number of parking spaces." Flexibility also can take the form of unbundling the cost of providing parking from the cost of building (or renting) housing (Daisa 2004; Shoup 2005). This would allow developers to better scale the amount of parking provided to what each tenant or homeowner is willing to pay for each car owned-i.e., let the market demand, rather than a possibly outdated government fiat, determine supply. And flexibility can be in the form of allowing TOD tenants to choose deeply discounted transit passes for frequent riders instead of a 300 square foot parking space. Shoup (2005 p. 259) argues that the substitution of such "Eco Passes" for parking among transit-oriented residents could "reduce the cost of TOD, improve urban design, reduce the need for variances, and reduce traffic congestion, air pollution, and energy consumption ... at a low cost."

Our finding that TODs de-generate automobile trips a lot more than they degenerate parking demand, at least relative to ITE standards, suggests TOD residents commute by transit proportionately more than they shed cars. That is, many self-select into TOD neighborhoods for the very reason that they want to avoid congestion and thus take transit to work, but for non-work travel, they still need a car. We believe a significant share of TOD residents would shed a car if they had carsharing options. Cervero et al. (2007) carried out a panel study of how San Francisco's City CarShare program affected car ownership. Four years after the inauguration of City CarShare, 29 percent of carshare members had gotten rid of one or more of their cars, and 63 percent lived in zero-vehicle households. A predictive 
model showed that living close to a carshare pick-up spot was strongly associated with car-shedding. By extension, putting shared-cars in and around TODs could relieve many households from owning a second car or a vehicle altogether. Through a combination of proximity advantages and lifestyle predispositions, living near transit can de-generate vehicle trips. And with the option of car-sharing, it can likely reduce parking demands as well.

\section{References}

Bernick, M., and R. Cervero. 1997. Transit Villages for the 21st Century. New York: McGraw-Hill.

Boarnet, M., and R. Crane. 2001. Travel by Design: The Influences of Urban Form on Travel. New York, Oxford University Press.

Cervero, R. 1994. Transit-based housing in California: Evidence on ridership impacts. Transport Policy 1(3): 174-183.

Cervero, R. 2001. Walk-and-ride: Factors influencing pedestrian access to transit. Journal of Public Transportation 3(4): 1-23.

Cervero, R., and others. 2004. Transit Oriented Development in America: Experiences, Challenges, and Prospects. Washington, D.C.: Transit Cooperative Research Program, Report, 102.

Cervero, R. 2007. Transit oriented development's ridership nonus: A product of self selection and public policies. Environment and Planning A 39: 2068-2085.

Cervero, R., A. Golub, and B. Nee. 2007. City CarShare: Longer-term travel-demand and car ownership impacts. Transportation Research Record 199: 70-80.

Cervero, R., and G. Arrington. 2008. Vehicle Trip Reduction Impacts of TransitOriented Housing. Journal of Public Transportation, 11 (3): 1-17.

Daisa, J. 2004. Traffic, parking, and transit oriented development. In Dittmar, H., and G. Ohland, eds. The New Transit Town: Best Practices in Transit-Oriented Development. Washington, DC: Island Press, pp. 114-129.

Dill, J. 2006. Travel and Transit Use at Portland Area Transit-Oriented Developments (TODs). Seattle: Final Technical Report, Transportation Northwest (TransNow). 
Dunphy, R. 2004. Who, What, Where, Why. In DunphyR., et al., eds. Developing Around Transit: Strategies and Solutions That Work. Washington, D.C.: Urban Land Institute, Chapter One.

Dunphy, R., D. Myerson, and M. Pawlukiewicz. 2004. Ten Principles for Developing Around Transit. In Dunphy, R., et al., eds., Developing Around Transit: Strategies and Solutions That Work. Washington, D.C.: Urban Land Institute, Chapter Seven.

Ewing, R., and R. Cervero. 2001. Travel and the built environment: A synthesis. Transportation Research Record 1780: 87-114.

Fink, A. 2003. The Survey Kit. Thousand Oaks, California: Sage Publications.

Handy, S. 2005. Smart Growth and the transportation-land use connection: What does the research tell us? International Regional Science Review 28(2): 1-22.

Hess, D., and P. Lombardi. 2004. Policy support for and barriers to transit-oriented development in the inner city: Literature review. Transportation Research Record 1887: 26-33.

Institute of Transportation Engineers. 2003. Parking Generation. Washington: ITE, 3rd Edition.

Karp, J. 2008. Suburbs a mile too far for some. Wall Street Journal, June 17, 2008, A18.

Loukaitou-Sideris, A., and T. Banjaree. 2000. The blue line blues: Why the vision of transit village may not materialize despite impressive growth in transit ridership. Journal of Urban Design 5(2): 101-125.

Lund, H., R. Willson, and R. Cervero. 2006. A re-evaluation of travel behavior in California TODs. Journal of Architecture and Planning Research 23(3): 247-263.

Poticha, S., and J. Wood. 2008. Transit oriented for all: Delivering mixed-income housing in transit served neighbourhoods. In Curtis, C., et al., eds., Transportation Oriented Development: Making It Happen. Surrey, England: Ashgate, 153-169.

Renne, J. 2009a. From transit-adjacent to transit-oriented development. Local Environment 14(1): 1-15. 
Renne, J. 2009b. Measuring the success of transit oriented development. In Curtis,

C., et al., eds., Transportation Oriented Development: Making It Happen. Surrey, England: Ashgate, pp. 241-255.

Shoup, D. 2003. Truth in transportation planning. Journal of Transportation and Statistics 6: 1-16.

Shoup, D. 2005. The High Cost of Free Parking. Chicago: Planner's Press.

Urban Land Institute. 2004. Emerging Real Estate Markets: 2004. Washington: ULI.

Willson, R. 2000. Reading Between the regulations: Parking requirements, planners' perspectives, and transit. Journal of Public Transportation 3(1): 111-128.

\section{About the Authors}

ROBert Cervero (robertc@berkeley.edu) is professor of City and Regional Planning at the University of California, Berkeley, where he also directs the Institute of Urban and Regional Development and the University of California Transportation Center (UCTC).

Arlie Adkins (adkins@pdx.edu) is a recent graduate in City Planning at the University of California, Berkeley and is currently enrolled in the doctoral program in Urban Studies at Portland State University. He previously worked as a transit planner with Portland's TriMet.

Cathleen Sullivan (cathleenscottsullivan@gmail.com) just completed a Masters in City Planning at the University of California, Berkeley. She now works as a transportation planner for Nelson/Nygaard Consulting Associates in San Francisco. 